JPE (Jurnal Pendidikan Edutama) Vol. 6 No. 2 Juli 2019

P-ISSN : 2339-2258 (Print) E-ISSN: 2548-821X (Online)

http://ejurnal.ikippgribojonegoro.ac.id/index.php/JPE

\title{
PENINGKATAN KEMAMPUAN BERBICARA MENGGUNAKAN METODE KOOPERATIF TIPE NHT PADA MAHASISWA TINGKAT I-A PBSI TAHUN AKADEMIK 2018/2019
}

\author{
Agus Darmuki ${ }^{1)}$, Nur Alfin Hidayati ${ }^{2)}$ \\ ${ }^{1,2}$ FPBS, IKIP PGRI Bojonegoro \\ 1agus_darmuki@yahoo.co.id \\ 2nikidanajwasalsabila@gmail.com
}

\begin{abstract}
The purpose of this research is to improve: (1) the quality of the learning process by using the cooperative type NHT method on PBSI study program level I-A IKIP PGRI Bojonegoro and (2) speaking skills by applying the cooperative type NHT method on PBSI I-A IKIP PGRI Bojonegoro study program students. This research is a classroom action research. The subjects of this study were I-A level students with 32 students consisting of 24 female students and 8 male students and speaking skills lecturers. The object of this research is learning to speak. Data collection techniques used were observation, in-depth interviews, and document analysis. The data validity technique uses data source triangulation techniques and method triangulation. The data analysis technique used is a comparative description analysis technique and interactive analysis. This research was conducted in two cycles which included four stages, namely: planning, implementation, observation, and reflection. The results showed an increase in learning speaking skills, marked by an increase in the number of students who reached the completeness limit, namely in the first cycle there were 5 students (16\%) and the second cycle 28 students (87.5\%). The average value of students has increased, namely 64.1 in the first cycle and 75.3 in the second cycle. This proves that the application of the NHT type cooperative method can increase student activeness, process and learning outcomes of student speaking skills.
\end{abstract}

Keywords: Ability, Speak, Method, Cooperative, Type NHT

\begin{abstract}
Abstrak
Tujuan penelitian ini untuk meningkatkan: (1) kualitas proses pembelajaran berbicara dengan menggunakan metode kooperatif tipe NHT pada mahasiswa prodi PBSI tingkat I-A IKIP PGRI Bojonegoro dan (2) keterampilan berbicara dengan menerapkan metode kooperatif tipe NHT pada mahasiswa prodi PBSI tingkat I-A IKIP PGRI Bojonegoro. Penelitian ini merupakan penelitian tindakan kelas. Subjek penelitian ini adalah mahasiswa tingkat I-A dengan jumlah 32 mahasiswa yang terdiri atas 24 mahasiswa perempuan dan 8 mahasiswa laki-laki dan dosen pengampu matakuliah keterampilan berbicara. Objek penelitian ini adalah pembelajara berbicara. Teknik pengumpulan data yang digunakan adalah observasi, wawancara mendalam, dan analisis dokumen. Teknik validitas data menggunakan teknik triangulasi sumber data dan triangulasi metode. Teknik analisis data yang digunakan adalah teknik analisis deskripsi komparatif dan analisis interaktif. Penelitian ini dilakukan dalam dua siklus yang meliputi empat tahapan, yaitu: perencanaan, pelaksanaan, observasi, dan refleksi. Hasil penelitian menunjukkan adanya peningkatan pembelajaran keterampilan berbicara, ditandai dengan meningkatnya jumlah mahasiswa yang mencapai batas ketuntasan, yaitu pada siklus I ada 5 mahasiswa (16\%) dan siklus II 28 mahasiswa (87,5\%). Nilai rata-rata mahasiswa mengalami peningkatan yaitu 64,1 pada siklus I dan 75,3 pada siklus II. Hal ini membuktikan bahwa penerapan metode kooperatif tipe NHT dapat meningkatkan keaktifan mahasiswa, proses dan hasil pembelajaran keterampilan berbicara mahasiswa.
\end{abstract}

Kata kunci:Kemampuan, Berbicara, Metode, Kooperatif, Tipe NHT. 


\section{PENDAHULUAN}

Sejalan dengan perkembangan kehidupan demokrasi yang semakin baik, keterampilan berbicara mahasiswa sebagai agen perubahan di segala aspek betul-betul sangat diharapkan oleh masyarakat luas (Darmuki dkk., 2017: 44). Perlu digarisbawahi peran mahasiswa sebagai kader bangsa yang memang aktaulisasinya ditandai dengan kemampuan berbicara. Kemampuan berbicara mahasiswa akan menunjukkan intelektualnya dalam menyampaikan ide gagasan atau informasi kepada orang lain (Darmuki dkk., 2018: 115). Berbicara adalah keterampilan penting dalam pembelajaran bahasa yang memungkinkan pembelajar bahasa untuk berkomunikasi tidak hanya dalam mengekspresikan sudut pandang tetapi juga dalam memberikan tanggapan (Richard, 2008: 7). Berdasarkan Luoma (2004: 20), keterampilan ini didefinisikan sebagai proses strategis yang melibatkan penutur menggunakan bahasa dalam komunikasi tertentu untuk mencapai tujuan tertentu pula.

Kemampuan berbicara merupakan keterampilan penting yang harus dimiliki oleh mahasiswa untuk melatih berpikir kritis dan dapat menyajikan suatu pendapat, pikiran, atau perasaan kepada seseorang atau suatu kelompok massa (Bygate, 2000: 20). Seseorang yang mahir berbicara akan dengan mudah dapat menguasai massa dan secara tidak langsung akan mampu memaparkan gagasannya sehingga dapat mudah diterima oleh orang lain (Hengki, dkk, 2017: 311).

Kenyataan di lapangan menunjukkan bahwa mahasiswa program studi PBSI IKIP PGRI Bojonegoro dalam pembelajaran matakuliah berbicara masih rendah. Kemampuan mahasiswa dalam mempraktikkan kemampuan berbicara yang rendah disebabkan oleh beberapa faktor yaitu pembelajran berbicara yang dilakukan dosen masih cenderung berorientasi pada transfer pengetahuan semata dengan metode monoton dan bersifat konvensional, serta dosen kurang variatif dalam menggunakan metode pembelajaran. Selain itu, mahasiswa juga mengalami hambatan pada keterampilan berbicara, yakni sering mengalami kesulitan saat berbicara. Hal inilah yang merupakan salah satu faktor mahasiswa kurang mampu mengungkapkan pendapatnya secara lisan. Dari hasil wawancara dengan dosen mata kuliah berbicara diperoleh keterangan bahwa hal itu terjadi karena mereka tidak terbiasa dan merasa takut ketika harus berbicara di muka umum.

Berdasarkan wawancara, beberapa mahasiswa mengatakan masih kurang percaya diri saat praktik berbicara di depan kelas dan kesulitan untuk merangkai katakata yang tepat. Frekuensi latihan berbicara juga kurang. Masalah atau topik yang dibicarakan kurang relevan dengan kehidupan sehari-hari. Faktor- faktor tersebut mengakibatkan mahasiswa kurang terampil berbicara dan menjadikannya kurang berpikir kritis. Hal ini teridentifikasi dari deskripsi nilai unjuk kerja berbicara, Berdasarkan jumlah keseluruhan mahasiswa sebanyak 32 orang, ada 31 (97\%) mahasiswa masih belum tuntas, masih memperoleh nilai kurang dari 75 . Ada 10 (31\%) mahasiswa mendapatkan nilai $\quad 65, \quad 15 \quad(47 \%)$ mahasiswa memperoleh nilai $60,1(3,1 \%)$ mahasiswa mendapat nilai 55, 5 (16\%) mahasiswa yang mendapat nilai 50 dan 1 (3,1\%) mahasiswa mendapat nilai 75 . Mahasiswa yang tuntas dalam pembelajaran berbicara pada survei awal ini ada 1 (3,1\%) mahasiswa. Dengan demikian, nilai terendah pada pembelajaran berbicara pratindakan ini adalah 50 sebanyak $5(16 \%)$ mahasiswa. Nilai tertinggi pembelajaran 
berbicara ini adalah 75 yang berhasil diperoleh oleh $1(3,1 \%)$

Hal tersebut sejalan dengan pendapat Stephens, dkk, (2000: 552) berikut:

However, Betsy and Eleanor started to teach the children about strategies as well as skills and simultaneously to pay attention to not only what they wanted the students to learn but also to what the children were learning and to how the children were learning.

Pernyataan tersebut menegaskan jika dosen menghendaki pembelajaran yang baik, dosen harus memahami metode dalam pembelajaran. Keterampilan berbicara mahasiswa tidak datang dengan sendirinya, tetapi harus terus dibina dan dikembangkan agar keterampilam berbicara yang dimiliki dapat bersifat komunikatif dan menarik. Hal ini dapat dilaksanakan oleh dosen secara aktif dan terus-menerus dengan mengadakan latihan-latihan dan praktik berbicara yang teratur dan berkelanjutan. Keahlian dosen dalam mengajar juga harus diikuti dengan penggunaan strategi yang baik agar pembelajaran dapat berhasil. Sebagaimana Regina dan Mulyadi (2015: 52) menjelaskan bahwa salah satu metode pembelajaran kooperatif yang dapat membantu meningkatkan kemampuan mahasiswa dalam proses belajar berbicara adalah Numbered Head Together (NHT), yaitu suatu metode pembelajaran yang lebih memungkinkan mahasiswa untuk aktif dan bertanggungjawab penuh untuk memahami materi pelajaran baik secara berkelompok maupun individual. Hal itu merupakan salah satu cara agar terbentuk suatu pendidikan yang berkarakter (tanggungjawab), karena dengan metode tersebut mahasiswa dituntut untuk lebih aktif dan bertanggungjawab dalam proses pembelajaran sehingga terbentuk karakter pada diri mahasiswa dengan kecakapan yang dimiliki.
Menurut Lie (2002:59), metode pembelajaran numbered head together memberikan kesempatan kepada mahasiswa untuk saling membagikan ide dan mempertimbangkan jawaban yang paling tepat dan mendorong mahasiswa untuk meningkatkan semangat kerja sama. Metode numbered head together merupakan salah satu dari pembelajaran kooperatif.

Tipe pembelajaran kooperatif yang dikemukakan oleh beberapa ahli, antara lain Slavin (1985), Lazarowitz (1988) atau Sharan \& Sharan (1992) salah satunya adalah pembelajaran tipe NHT yang dikembangkan oleh Kagan (1993). Pada umumnya, NHT digunakan untuk melibatkan mahasiswa dalam penguatan pemahaman pembelajaran atau mengecek pemahaman mahasiswa terhadap materi pembelajaran. Metode NHT merupakan tipe pembelajaran kooperatif yang terdiri atas empat tahap yang digunakan untuk mereview fakta-fakta dan informasi dasar yang berfungsi untuk mengatur interaksi mahasiswa.

Metode pembelajaran kooperatif tipe numbered head together dapat disimpulkan sebagai suatu cara penyajian pelajaran dengan melakukan percobaan, mengalami dan membuktikan sendiri sesuatu permasalahan yang dipelajari. Dengan metode kooperatif tipe numbered head together mahasiswa diberi kesempatan untuk mengalami sendiri atau melakukan sendiri, mengikuti suatu proses, mengamati suatu objek, menganalis, membuktikan dan menarik kesimpulan sendiri tentang suatu objek dan keadaan suatu proses pembelajaran tertentu.

Menurut Arends (2008: 16), langkah-langkah yang dapat dilakukan dosen dalam pelaksanaan pembelajaran kooperatif tipe Numbered Head Together adalah sebagai berikut: (1) Penomoran 
(Numbering), Dosen membagi mahasiswa dalam kelompok-kelompok dengan 3 sampai 5 anggota dan memberi mereka nomor sehingga masing-masing mahasiswa dalam kelompok memiliki nomor yang berbeda 1 sampai 5; (2) Memberi Pertanyaan (Questioning), Dosen mengajukan pertanyaan pada mahasiswa. Pertanyaan ini dapat bervariasi dalam bentuk pertanyaan yang spesifik ataupun dalam bentuk pernyataan; (3) Berpikir Bersama (Heads Together), Mahasiswa berpikir bersama-sama dalam kelompok untuk menemukan jawabannya dan memastikan setiap anggota kelompok mengetahui jawaban tersebut;

Menjawab pertanyaan (Answering), Dosen menyebutkan nomor tertentu dan mahasiswa dari setiap kelompok yang memiliki nomor tersebut mengangkat tangannya dan memberikan jawaban pada seluruh anggota kelas.

Penilaian proses berlangsung dengan menggunakan lembar penilaian sikap (afektif) yang terdiri dari aspek: (1) keaktifan mahasiswa; (2) minat dan antusiasme; (3) berani berbicara di depan kelas sedangkan dalam penilain hasil, ada beberapa aspek yang dinilai, yaitu (1) tekanan; (tata bahasa); (3) kelancaran; (4) pemahaman; (5) kosa kata (Hughes, 2003: 54).

\section{METODE PENELITIAN}

Penelitian ini merupakan penelitian tindakan kelas yang dilakukan di prodi PBSI tingkat I-A IKIP PGRI Bojonegoro Tahun Akademik 2018/2019 semester ganjil. Subjek penelitian ini adalah mahasiswa tingkat I-A dengan jumlah 32 orang yang terdiri atas 24 mahasiswa perempuan dan 8 mahasiswa laki-laki serta seorang dosen pengampu matakuliah keterampilan berbicara. Objek penelitian ini adalah kegiatan pembelajaran berbicara.
Teknik pengumpulan data yang digunakan adalah observasi, wawancara mendalam, dan analisis dokumen. Observasi digunakan untuk mengamati kegiatan proses pembelajaran berbicara di kelas. Wawancara digunakan untuk mengetahui respon mahasiswa dan dosen mengenai kegiatan pembelajaran berbicara yang dilaksanakan di kelas. Dokumentasi yang digunakan berupa hasil pembelajaran dan foto kegiatan penelitian berlangsung. Teknik validitas data menggunakan teknik triangulasi sumber data dan triangulasi metode. Teknik analisis data yang digunakan adalah teknik analisis deskripsi komparatif dan analisis interaktif. Penelitian ini dilakukan dalam dua siklus yang meliputi empat tahapan, yaitu: perencanaan, pelaksanaan, observasi, dan refleksi. Kemmis menyebutkan empat aspek dalam penelitian tindakan kelas, yaitu: perencanaan tidakan (planning), pelaksanaan tindakan (acting), pengamatan (observasing) dan refleksi (reflecting). PTK merupakan penelitian yang bersiklus. Artinya, penelitian ini dilakukan secara berulang dan berkelanjutan sampai tujuan penelitian dapat tercapai.

\section{HASIL DAN PEMBAHASAN}

Sebelum melaksanakan penelitian, peneliti melakukan survey awal yang bertujuan untuk mengetahui kondisi awal proses pembelajaran berbicara. Selain itu, servei awal ini juga dimanfaatkan untuk mengetahui kemampuan awal berbicara mahasiswa . Berdasarkan kegiatan survei awal ini, peneliti menyimpulkan bahwa kualitas proses dan hasil pembelajaran berbicara mahasiswa tingkat I-A Prodi PBSI IKIP PGRI Bojonegoro masih perlu diperbaiki. Kemudian, peneliti berkolaborasi dengan dosen untuk mengatasi masalah tersebut dengan menerapkan metode kooperatif tipe 
numbered head together dalam proses pembelajaran berbicara.

Selain itu, peneliti dan dosen menyusun rencana untuk siklus I. Pada pelaksanaan siklus I, pembelajaran berbicara diterapkan dengan metode kooperatif tipe numbered head together. Kenyataan di lapangan, masih terdapat kelemahan atau kekurangan pada siklus I. Kelemahan atau kekurangan tersebut berasal dari pihak dosen, mahasiswa, dan metode yang digunakan. Kelemahan ditemukan dari dosen, yaitu; (1) dosen kurang jelas dalam memberikan perintah sehingga mahasiswa masih terlihat bingung; (2) dosen kurang memberikan bimbingan secara intens ketika mahasiswa bekerja dalam kelompok; (3) dosen jarang menegur mahasiswa yang tidak aktif atau tidak fokus ketika pelajaran berlangsung. Kelemahan yang ditemukan dari mahasiswa , yaitu; (1) mahasiswa terlihat belum sepenuhnya aktif dalam mengikuti pembelajaran. Sebagian mahasiswa masih melakukan aktivitas pribadi, seperti mengganggu teman, bercanda dengan teman, dan belum berani menjawab pertanyaan dari dosen; (2) mahasiswa masih ada yang hanya diam saja ketika melakukan kerja kelompok; (3) mahasiswa kurang bisa mengoptimalkan waktu dengan baik. Ketika waktu yang diberikan dosen sudah habis, mahasiswa sering belum selesai dalam mengerjakan tugas yang diberikan; (4) mahasiswa belum melaksanakan peran sebagai anggota kelompok dengan baik; (5) pada umumnya mahasiswa masih kesulitan saat berbicara, terbukti saat berbicara masih banyak mahasiswa yang kurang percaya diri dan masih bertanya-tanya pada teman satu kelompok dan melihat catatan. Selain itu, mereka masih banyak melakukan kesalahan pada saat berbicara. Kosa kata yang digunakan masih terbatas (sama), berbicara masih belum lancar, lafal kurang jelas dan intonasi masih monoton. Kelemahan pembelajaran berbicara dengan metode nkooperatif numbered head together, yaitu mahasiswa merasa metode tersebut asing dan baru sehingga belum begitu memahami metode tersebut.

Selanjutnya, peneliti dan dosen berdiskusi dan sepakat akan mengadakan siklus II sebagai perbaikan terhadap kekurangan yang ditemukan pada siklus I. Pada siklus II ini dosen juga menerapkan metode kooperatif tipe numbered head together dalam pembelajaran berbicara. Berdasarkan pelaksanaan siklus II terbukti bahwa telah terjadi peningkatan proses dan hasil pembelajar berbicara yang cukup signifikan dari siklus I. Pada siklus I mahasiswa yang dinyatakan tuntas ada 5 mahasiswa dan pada siklus II terjadi peningkatan menjadi 28 mahasiswa .

Tabel 1. Hasil Pembelajaran Berbicara Mahasiswa

\begin{tabular}{cccccc}
\hline \multirow{2}{*}{ No } & Nilai & \multicolumn{3}{c}{ Jumlah Mahasiswa } & \\
\cline { 3 - 5 } & & Pratindakan & $\begin{array}{c}\text { Siklus } \\
1\end{array}$ & $\begin{array}{c}\text { Siklus } \\
2\end{array}$ & Keterangan \\
\hline 1 & $45-54$ & 5 & 0 & 0 & $\begin{array}{c}\text { Tidak } \\
\text { Tuntas }\end{array}$ \\
\hline 2 & $55-64$ & 16 & 0 & 1 & $\begin{array}{c}\text { Tidak } \\
\text { Tuntas }\end{array}$ \\
\hline 3 & $65-74$ & 10 & 27 & 3 & $\begin{array}{c}\text { Tidak } \\
\text { Tuntas }\end{array}$ \\
\hline 4 & $75-84$ & 1 & 5 & 27 & Tuntas \\
\hline 5 & $85-94$ & 0 & 0 & 1 & Tuntas \\
\hline
\end{tabular}


Berdasarkan tindakan-tindakan tersebut, dosen berhasil menerapkan pembelajaran kooperatif tipe numbered head together yang mampu meningkatkan kemampuan mahasiswa dalam berbicara. Selain itu, penelitian ini juga bermanfaat untuk meningkatkan kinerja dosen dalam melaksanakan pembelajaran mata kuliah berbicara dan dalam melaksanakan pembelajaran yang efektif dan menarik di kelas. Penggunaan metode kooperatif tipe numbered head together ini juga dapat meningkatkan kerjasama mahasiswa dalam proses pembelajaran keterampilan berbicara. Hal ini disebabkan dalam metode kooperatif tipe numbered head together semua mahasiswa mempunyai peran untuk berbicara secara bergantian. Ketika melaksanakan diskusi, mahasiswa dituntut untuk memahami materi, aktif dalam diskusi, dan mampu mentransfer kepada teman satu kelompok atau kelompok lainnya. Penggunaan metode kooperatif tipe numbered head together mampu menjadikan para mahasiswa aktif selama proses pembelajaran sehingga hasil praktik berbicara mereka juga meningkat. Selain itu mahasiswa menjadi lebih antusias dan berminat dalam mengikuti pembelajaran berbicara. Bentuk antusiasme dan minat tersebut terlihat dari banyaknya mahasiswa yang aktif memberikan respon terhadap apersepsi yang diberikan dosen, memperhatikan penjelasan materi yang diberikan dosen, dan aktif dalam berdiskusi kelompok. Sesuai dengan pendapat Trianto (2007: 45) bahwa pembelajaran kooperatif tipe NHT dapat meningkatkan prestasi mahasiswa, kepercayaan diri, rasa saling memiliki (ketergantungan positif), antusiasme (minat) dan meningkatkan pemahaman mahasiswa terhadap materi pembelajaran.

Keberhasilan metode kooperatif tipe numbered head together dalam meningkatkan keaktifan mahasiswa selama proses pembelajaran dan kemampuan mahasiswa dalam berbicara dapat dilihat dari indikator-indikator sebagai berikut.

Tabel 2. Hasil Observasi Keaktifan Mahasiswa dalam Pembelajaran

\begin{tabular}{clcc}
\hline \multirow{2}{*}{ No } & & Indikator & \multicolumn{2}{c}{$\begin{array}{c}\text { Presentasi yang } \\
\text { Dicapai }\end{array}$} \\
\cline { 3 - 4 } & & Siklus 1 & $\begin{array}{c}\text { Siklus } \\
2\end{array}$ \\
\hline 1 & Keaktifan mahasiswa selama apersepsi & $20 \%$ & $78 \%$ \\
\hline 2 & $\begin{array}{l}\text { Keaktifan mahasiswa dalam } \\
\text { memperhatikan penjelasan materi dosen }\end{array}$ & $37 \%$ & $93,7 \%$ \\
\hline 3 & $\begin{array}{l}\text { Keberanian mahasiswa dalam } \\
\text { mengungkapkan pendapat (berbicara) }\end{array}$ & $50 \%$ & $81 \%$ \\
\hline 4 & Keaktifan mahasiswa dalam diskusi & $46 \%$ & $78 \%$ \\
\hline 5 & Ketuntasan hasil belajar berbicara & $16 \%$ & $87 \%$ \\
\hline
\end{tabular}

Keaktifan mahasiswa selama pembelajaran keterampilan berbicara mengalami peningkatan. Hal ini terlihat dari indikator keaktifan mahasiswa dalam pembelajaran yang selalu mengalami peningkatan di setiap siklusnya. Tindakan berupa penerapan metode kooperatif tipe numbered head together yang dilaksanakan tiap siklus mampu meningkatkan keaktifan mahasiswa tingkat I-A Prodi PBSI IKIP PGRI Bojonegoro selama pembelajaran berbicara.
Hasil pengamatan peneliti dapat diketahui bahwa keaktifan mahasiswa pada siklus I mencapai 38,3\%. Pada siklus II, keaktifan mahasiswa meningkat menjadi $83 \%$. Mahasiswa yang aktif dalam siklus ini mencapai 27 mahasiswa dari 32 mahasiswa yang hadir pada hari itu. Berdasarkan hasil pengamatan peneliti di atas, maka dapat dikatakan bahwa tindakan yang dilakukan dosen untuk meningkatkan keaktifan mahasiswa cukup berhasil. Hal ini membuktikan bahwa metode kooperatif 
numbered head together memiliki peranan penting dalam meningkatkan keaktifan, tanggungjawab dan mahasiswa lebih fokus pada proses belajar mengajar. Sesuai pendapat Slavin (2008: 256) pembelajaran menomori bersama sangat baik untuk menambahkan tanggung jawab individual kepada diskusi kelompok, karena sebelumnya tidak diberi tahu siapa akan mewakili kelompok dalam mengemukakan jawaban sehingga setiap mahasiswa menjadi lebih fokus dan aktif. Peningkatan segi keaktifan mahasiswa ini dapat dilihat dari indikator berikut: (a) Meningkatnya respon mahasiswa selama apersepsi; (b) Keaktifan mahasiswa dalam pembelajaran merupakan hal pokok dalam proses pembelajaran. Apersepsi merupakan langkah awal yang dilakukan dosenuntuk mengaktifkan mahasiswa terkait dengan pokok penting sebelum masuk ke dalam materi pelajaran. Pada apersepsi ini, dosen selalu memberikan pertanyaan sesuai dengan tema pelajaran yang akan dipelajari. Respon yang diberikan mahasiswa terhadap apersepsi yang diberikan dosen selalu mengalami peningkatan dari siklus ke siklus. Mahasiswa aktif selama pemberian apersepsi pada siklus I sebanyak 6 mahasiswa atau sekitar 20\%. Pada siklus II mengalami peningakatan menjadi $78 \%$ atau sebanyak 25 mahasiswa yang aktif selama apersepsi; (c) Meningkatnya perhatian mahasiswa pada saat dosen memberikan penjelasan materi. Perhatian dan fokus mahasiswa dalam proses pembelajaran merupakan hal yang sangat penting. Dosen untuk menumbuhkan perhatian tersebut, harus memotivasi mahasiswa dengan menerapkan cara-cara baru yang digunakan dalam proses pembelajaran. Dalam penelitian ini, dosen menggunakan metode kooperatif tipe numbered head together. Setelah tindakan tersebut dilaksakan perhatian mahasiswa dalam pembelajaran berbicara meningkat. Meningkatnya perhatian mahasiswa terhadap pembelajaran berbicara menggunakan kooperatif tipe numbered head together juga telah membuktikan bahwa telah tercipta suasana pembelajaran yang menyenangkan bagi mahasiswa (Kagan, 2009: 63). Dalam hal ini, mahasiswa meresa mendapatkan metode pembelajaran yang baru dari dosen. Mahasiswa yang aktif memperhatikan penjelasan dosen saat memberikan materi pada siklus I sebanyak 12 mahasiswa atau sekitar (37\%). Pada siklus II mengalami peningakatan menjadi $(93,7 \%)$ atau sebanyak 30 mahasiswa yang aktif memperhatikan penjelasan dosen; (d) Meningkatnya keaktifan mahasiswa dalam kegiatan berdiskusi. Diskusi yan dilakukan mahasiswa dalam pembelajaran ini bertujuan agar mahasiswa bekerja sama dengan temannya. Mahasiswa dengan kerja sama, diharapkan lebih memiliki rasa tanggung jawab terhadap pembelajarannya sendiri dan juga orang lain. Begitu pula Kagan (2009) menyatakan bahwa metode pembelajaran kooperatif bertumpu pada kerja kelompok kecil, berlawanan dengan pembelajaran klasikal (satu kelas penuh). Dengan demikian mahasiswa dituntut bekerja sama dalam diskusi dan saling membantu satu sama lain.

Peningkatan keaktifan mahasiswa terjadi pada kegiatan diskusi ini. Keaktifan selama berlangsungnya diskusi ini dapat dilihat dari peningkatan yang terjadi di setiap siklusnya. Pada siklus I, mahasiswa yang aktif dalam kegiatan diskusi sebanyak 15 mahasiswa atau sekitar (46\%) dan pada siklus II mengalami peningkatan menjadi 25 mahasiswa atau sekitar (78,1\%).

\begin{tabular}{lrr}
\multicolumn{1}{c}{ Keberanian } & mahasiswa \\
mengungkapkan & $\begin{array}{c}\text { pendapat } \\
\text { pembelajaran }\end{array}$ & berbicara, \\
sehingga
\end{tabular}


mahasiswa dituntut harus sering berlatih berbicara di muka umum. Salah satunya dengan cara mahasiswa harus berani mengungkapkan pendapatnya di depan teman-temannya. Berbicara memiliki hubungan erat dengan komunikasi, dimana berbicara merupakan bentuk kegiatan komunikasi lisan. Menurut Bygate (2000: 11), komunikasi adalah serangkaian perbuatan komunikasi yang dipergunakan secara sistematis untuk menyelesaikan atau mencapai maksud-maksud tertentu. Dengan demikian, mahasiswa dituntut mampu berbicara/ menyampaikan sebuah informasi agar dapat dipahami orang lain. Dalam penelitian ini, keberanian mahasiswa dalam mengungkapkan pendapat mengalami peningkatan pada setiap siklus. Pada siklus I, mahasiswa mampu mengungkapkan pendapatnya sebanyak 16 mahasiswa atau sekitar (50\%). Pada siklus II meningkat menjadi 26 mahasiswa atau sekitar $(81,3 \%)$ yang berani mengungkapkan pendapatnya. Pembelajaran berbicara yang dilakukan dengan kegiatan komunikatif dinilai lebih menyenangkan daripada yang tidak komunikatif (Green, 1993: 2; Hughes, 2002: 14).

Hasil pembelajaran keterampilan berbicara meningkat setelah menggunakan metode kooperatif tipe numbered head together. Sebelum tindakan ini dilaksanakan, terdapat fakta bahwa nilai pembelajaran keterampilan berbicara rendah. Ada 31 mahasiswa yang tidak tuntas atau mendapat nilai kurang dari 75. Dengan demikian, persentase ketuntasan sebelum tindakan dilakukan hanya $(3,1 \%)$ atau hanya 1 mahasiswa yang tuntas. Bahkan sebelum dilakukan tindakan terdapat kesenjangan kemampuan mahasiswa dalam berbicara. Hal ini tampak dari hasil nilai berbicara mahasiswa sebelum tindakan, yakni 5 mahasiswa mendapat nilai 50, 1 mahasiswa mendapat nilai 55, 15 mahasiswa memperoleh nilai 60, 10 mahasiswa memperoleh nilai 65, dan ada 1 mahasiswa yang mendapat nilai 75. Pada pembelajaran tersebut, mahasiswa tampak belum merespon apersepsi yang diberikan dosen, serta tampak tidak bersemangat ketika mengikuti pembelajaran. Setelah dilaksanakan tindakan, tampak bahwa nilai pembelajaran diskusi mahasiswa mengalami peningkatan yang cukup signifikan. Mahasiswa mulai aktif merespon apersepsi yang diberikan dosen, serta tampak bersemangat ketika mengikuti pembelajaran berbicara. Pada siklus I ada 5 mahasiswa yang tuntas (16\%). Peningkatan cukup signifikan terjadi pada siklus II yaitu $28(87,5 \%)$ mahasiswa tuntas dari 32 mahasiswa yang hadir. Penggunaan metode kooperatif tipe numbered head together membuktikan bahwa mampu meningkatkan proses dan hasil pembelajaran keterampilan berbicara (Thuy, 2005; Tran, 2014; Kaur, 2017).

\section{SIMPULAN}

Penerapan metode kooperatif tipe numbered head together dapat meningkatkan keterampilan berbicara pada mahasiswa Prodi PBSI IKIP PGRI Bojonegoro Tahun Akademik 2018/2019. Hal ini dapat dibuktikann dengan meningkatnya jumlah mahasiswa yang mencapai batas ketuntasan, yaitu pada siklus I ada 5 mahasiswa yang tuntas (16\%) dan peningkatan cukup signifikan terjadi pada siklus II, yaitu 28 mahasiswa tuntas $(87,5 \%)$. Ketuntasan mahasiswa dalam pembelajaran keterampilan berbicara tersebut dinilai dari hasil unjuk kerja/ praktik berbicara mahasiswa. Nilai tersebut berdasarkan pada aspek lafal dan intonasi, kosakata, kelancaran, srtuktir kalimat, dan keberanian berpendapat.

\section{DAFTAR RUJUKAN}

Arends, Richard. I. (2008). Learning to teach. Yokyakarta: Pustaka Pelajar.

Bygate, Martin. (2000). Speaking. Oxford: Oxford University Press.

Darmuki, A., Andayani, Joko Nurkamto, Kundharu Saddhono. (2017). Evaluating Information-ProcessingBased Learning Cooperative Model 
on Speaking Skill Course. Journal of Language Teaching and Reasearch. 8(1), 44-51.

Darmuki, A., Andayani, Joko Nurkamto, Kundharu Saddhono. (2018). The Development and Evaluation of Speaking Learning Model by Cooperative Approach. International Journal of Instruction. 11(2), 115-128.

Green, J. M. (1993). Student Attitudes Toward Communicative and Non-Communicative Activities: Do Enjoyment and Effectiveness Go Together?. The Modern Language Journal, 77(1), 1-10.

Hengki, H.; Jabu, B. \& Salija, K. (2017). The effectiveness of cooperative learning strategy through english village for teaching speaking skill. Journal of Language Teaching and Research, 8(2), 306-312.

Kagan, S. (1993). Cooperative learning. San Juan Capistrano, CA: Resources for Teachers. Inc. Google Scholar.

Kagan, S. Kagan. (2009). cooperative learning. San Clemente: Kagan Publishing.

Kaur, M. (2017). Cooperative learning: An effective teaching strategy. International Educational Journal, 4(1), 9-20.

Lazarowitz, RH. (1988). Cooperative learning and group-investigation in Israel's Jewish and Arabs schools: A community approach. Theory Into Practice. Vol. 38, No. 2: 13105

Luoma, S. (2004). Assessing Speaking. Cambridge : Cambridge University Press.
Regina Rahmi, Mulyadi Syahputra. (2015). The Use of Number Heads Together (NHT) in Teaching Speaking for Junior High School. GEEJ. 2(1),37-53.

Richards, J., C. (2008). Teaching listening and speaking. Cambridge : Cambridge University Press.

Sharan, S. \& Sharan, Y. (1992) Expanding cooperative learning through group investigation, Colchester, VT: Teachers College Press.

Slavin, R. E. (1985). Cooperative learning: Theory, research, and practice. (2nd edition), Boston: Allyn and Bacon.

Slavin, Robert. E. 2008. Cooperative Learning. Bandung: Nusa Media.

Stephens, Diane dkk.. 2000. "Learning (about Learning) from Four Teachers." RTE Research in the Teaching of English. Volume 34, Nomor 4, Mei 2000: 552. NCTE Headquarters.

Thuy, Le Thi Bich. (2005). “An Action Research on the Application of cooperative Learning to Teaching Speaking”. TESOL. Journal. 1. 332349.

Tran. V. D. (2014). The effects of cooperative learning on the academic achievement and knowledge retention. International Journal of Higher Education, 3(2), 131-140.

Trianto. (2007). Model-Model Inovasi Pembelajaran Inovatif Berorientasi Konstruktivistik Konsep, Landasan Teoretik Praktis dan Implementasinya. Jakarta : Prestasi Pustaka. 
18JURNAL PENDIDIKAN EDUTAMA, Vol.6, No.2 Juli 2019 